\title{
Interbasin deep water exchange in the western Mediterranean
}

\author{
Monika Rhein, ${ }^{1}$ Uwe Send, ${ }^{2}$ Birgit Klein, ${ }^{3}$ and Gerd Krahmann ${ }^{4}$
}

\begin{abstract}
Owing to its nearly enclosed nature, the Tyrrhenian Sea at first sight is expected to have a small impact on the distribution and characteristics of water masses in the other basins of the western Mediterranean. The first evidence that the Tyrrhenian Sea might, in fact, play an important role in the deep and intermediate water circulation of the entire western Mediterranean was put forward by Hopkins [1988]. There, an outflow of water from the Tyrrhenian Sea into the Algero Provençal Basin was postulated in the depth range $700-1000 \mathrm{~m}$, to compensate for an observed inflow of deeper water into the Tyrrhenian Sea. However, this outflow, the Tyrrhenian Deep Water (TDW), was undetectable since it would have hydrographic characteristics that could also be produced within the Algero-Provençal Basin. A new data set of hydrographic, tracer, lowered Acoustic Doppler Current Profiler (LADCP), and deep float observations presented here allows us now to identify and track the TDW in the Algero-Provençal Basin and to demonstrate the presence and huge extent of this water mass throughout the western Mediterranean. It extends from $600 \mathrm{~m}$ to $1600-1900 \mathrm{~m}$ depth and thus occupies much of the deep water regime. The outflow from the Tyrrhenian is estimated to be of the order of $0.4 \mathrm{~Sv}\left(\mathrm{~Sv}=10^{6} \mathrm{~m}^{3} \mathrm{~s}^{-1}\right)$, based on the tracer balances. This transport has the same order of magnitude as the deep water formation rate in the Gulf of Lions. The Tyrrhenian Sea effectively removes convectively generated deep water (Western Mediterranean Deep Water (WMDW)) from the Algero-Provençal Basin, mixes it with Levantine Intermediate water (LIW) above, and reinjects the product into the Algero-Provençal Basin at a level between the WMDW and LIW, thus smoothing the temperature and salinity gradients between these water masses. The tracer characteristics of the TDW and the lowered ADCP and deep float observations document the expected but weak cyclonic circulation and larger flows in a vigorous eddy regime in the basin interior.
\end{abstract}

\section{Introduction}

The connections of the Tyrrhenian Sea to the adjacent basins are mostly shallow (Figure 1). The sea's principal openings are the Corsica Channel in the north with a sill depth of about $450 \mathrm{~m}$, and the broad opening between Sardinia and Sicily to the southwest. The Sardinia Channel is the communication with the AlgeroProvençal Basin and includes the narrow Tyrrhenian Trough with a depth of about $1920 \mathrm{~m}$ and a cross section of $50 \mathrm{~km}^{2}$ below $500 \mathrm{~m}$ depth [Hopkins, 1988]. The

\footnotetext{
'Baltic Sea Reaserach Institute, Rostock-Warnemünde, Germany. ${ }^{2}$ Institut für Meereskunde, Kiel Germany.

${ }^{3}$ Institut für Umweltphysik, Universităt Bremen, Bremen Germany.

${ }^{4}$ Lamont-Doherty Earth Observatory, Columbia University, Palisades, New York.
}

Copyright 1999 by the American Geophysical Union.

Paper number 1999JC900162.

0148-0227/99/1999JC900162.\$0900 shallow Straits of Messina (between Sicily and Italy) and Bonifacio (separating Sardinia and Corsica) are not considered to contribute significantly to the general intermediate and deep basin circulation [Astraldi and Gasparini, 1994]. Thus deep and intermediate water exchange (below $500 \mathrm{~m}$ depth) between the Tyrrhenian Sea and the Algero-Provençal Basin has to occur through the Sardinia Channel. The Strait of Sicily southeast of the Tyrrhenian Sea is relatively wide and shallow with a maximum depth of about $430 \mathrm{~m}$, connecting the eastern Mediterranean with the western part.

The deep and intermediate water exchange of the Tyrrhenian Sea has been studied by Hopkins [1988] using hydrographic data from the southern Tyrrhenian Sea and two current meters (at 347 and $1763 \mathrm{~m}$ depth) in the Tyrrhenian Trough, which were deployed for 70 days. Most of the time, the flow of the deep current meter was directed northeastward, into the Tyrrhenian Sea. Taking one of the two Conductivity-temperaturedepth (CTD) cross sections through the trough and adjusting the geostrophic velocity profile to the mean deep moored current meter velocity $\left(0.9 \mathrm{~cm} \mathrm{~s}^{-1}\right)$, a transport 


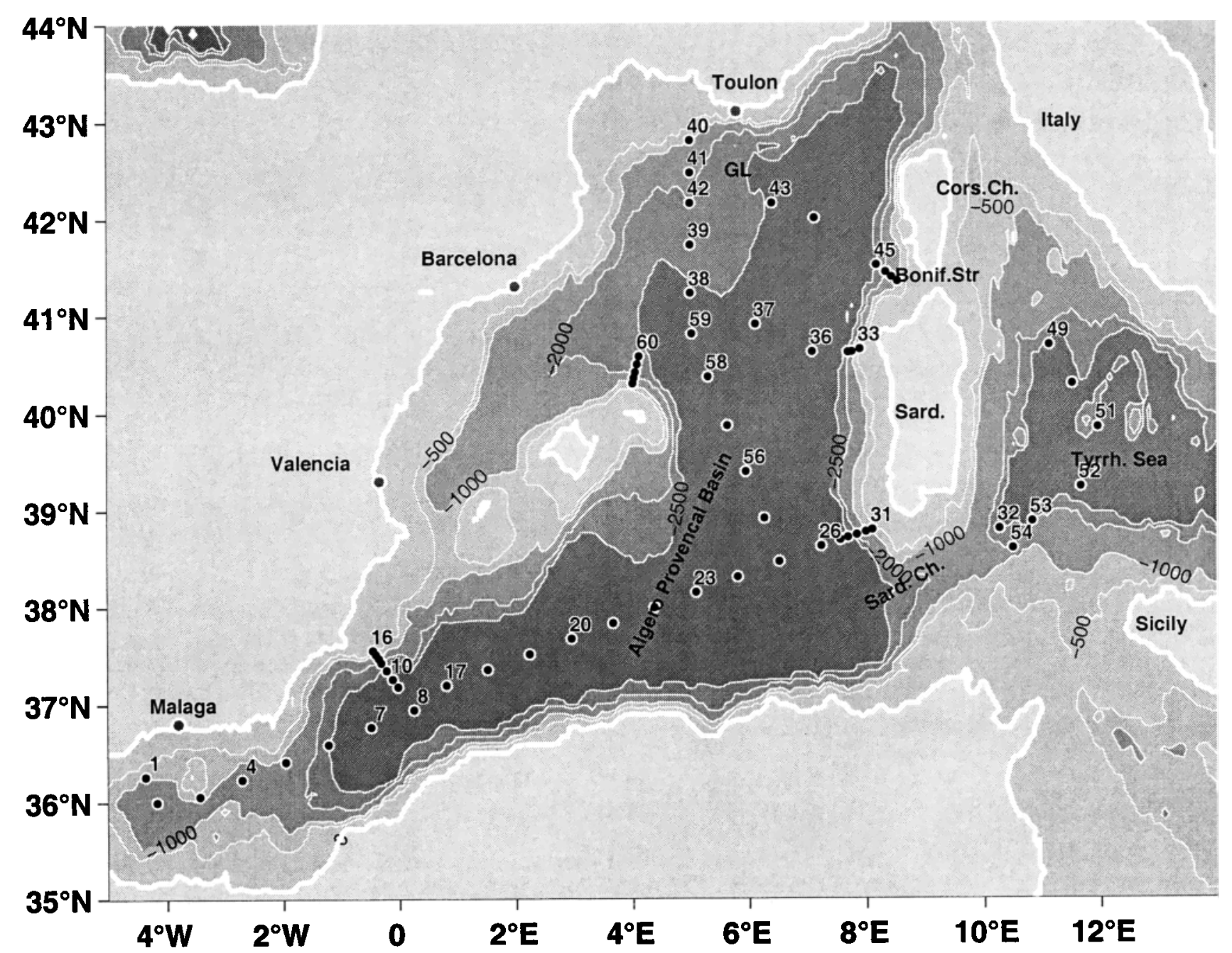

Figure 1. CTD/CFC and LADCP stations of the R/V Poseidon cruise 234, October 22 to November 12, 1997. Abbreviations as follows: Bonif.Str., Bonifacio Strait; Cors.Ch., Corsican Channel; GL., Gulf of Lions; Sard., Sardinia; Sard.Ch., Sardinian Channel; and Tyrrh.Sea, Tyrrhenian Sea. The Tyrrhenian Trough is near station 32. Not included in the map are the Strait of Messina and the Strait of Sicily farther east.

of $0.13 \mathrm{~Sv}$ deep water into the Tyrrhenian Sea was estimated. Owing to the lack of more data and the coarse assumptions used, this number (and the depth of the outflow given below) is subject to great uncertainties. However, if the order of magnitude was correct, the deep water import into the Tyrrhenian Sea would be comparable to the lower estimates of the annual deep water production in the Gulf of Lions ranging from 0.14 to $1.2 \mathrm{~Sv}$ [Bethoux, 1980; Send et al., 1995; Rhein, 1995; Krahmann, 1997]. In the Tyrrhenian Sea, the inflowing Western Mediterranean Deep Water (WMDW) from the Algero-Provençal Basin mixes with the overlying warm and saline Levantine Intermediate Water (LIW), upwells, and, according to Hopkins [1988], exits the Tyrrhenian Sea in depths of 700-1000 m. The depth of the outflow was estimated by Hopkins [1988] from the geostrophic velocity profile adjusted to the current meter mooring results, showing southeastward velocities above $1000 \mathrm{~m}$ depth. The magnitude of the Tyrrhenian Deep Water (TDW) outflow was calculated at $0.2 \mathrm{~Sv}$, assuming an approximate 2:1 mixture between WMDW and LIW. The mixing ratio was mainly based on the salinity balance.

Above the TDW, the LIW enters the Tyrrhenian Sea through the Strait of Sicily. Recent investigations by Astraldi et al. [1996] showed that the inflow into the Tyrrhenian, originating in the eastern Mediterranean, contains not only LIW (Salinity $S=38.76$, potential temperature $\Theta=13.9^{\circ} \mathrm{C}$ ) but also a denser, less saline (38.72-38.74) and colder $\left(13.62-13.65^{\circ} \mathrm{C}\right)$ component. The mean annual transport of both water masses is estimated to be $1.0 \mathrm{~Sv}$, of which the main part seems to enter the Tyrrhenian Sea directly, without any deflection to the west [Astraldi et al., 1996]. A minor part of the LIW leaves the Tyrrhenian Sea in the north through the Corsica Channel, where a 2-year mean flow of about 
$0.15 \mathrm{~Sv}$ was measured by Astraldi and Gasparini [1992]. The major outflow, however, is through the Sardinian Channel in the south [Astraldi and Gasparini, 1994].

To summarize, below the surface water, the Tyrrhenian Sea receives LIW and a colder, fresher component from the eastern Mediterranean through the Strait of Sicily, and from the Algero-Provençal Basin, WMDW enters through the Tyrrhenian Trough south of Sardinia (above $1900 \mathrm{~m}$ depth). The export consists of LIW through the Corsica Channel and the Sardinian Channel and of TDW through the Tyrrhenian Trough into the Algero-Provençal Basin. The magnitude of the WMDW import and the magnitude and depth structure of the TDW export are subject to great uncertainites. Up until now it was not possible to detect the TDW export in the Algero-Provençal Basin, because it would have $\Theta-S$ characteristics that could also be produced locally in the Algero-Provençal Basin by mixing. Here we combine hydrographic and tracer distributions (chlorofluorocarbons (CFCs) and helium) taken in autumn 1997 with directly measured velocities from deep floats and lowered ADCP profiles to investigate the role of these exchanges in the deep water mass characteristics and the water mass distribution in both basins (Figure 1).

\section{Methods}

\subsection{CTD Data}

A CTD model Neil Brown Mark III was used. Salinity samples were drawn at each station from the $10 \mathrm{~L}$ Niskin bottles to calibrate the conductivity cell. The samples were analyzed on board with a Guildline salinometer. No temporal drift of the conductivity cell was detected. However, we obtained three profiles in the Algero-Provençal Basin (stations 55, 58, 59, for location, see Figure 1) with significantly higher salinities in the deep water compared with all the other stations, which was not reflected in the salinometer data. The salinities of these profiles were corrected separately. The pressure dependence of the conductivity sensor was corrected by a second-order polynomial fit. The laboratory calibration of the temperature sensor was confirmed by electronic thermometers attached to three of the water bottles. The precisions of the temperature and salinity data (excluding the above anomalous salinity profiles) were $\pm 0.003^{\circ} \mathrm{C}$ and \pm 0.004 , respectively.

\subsection{Chlorofluorocarbons}

About 800 CFC water samples (components CFC11 and CFC-12) were analyzed on board with the gas chromatographic technique described by Bullister and Weiss, [1988] . After some contamination problems at the beginning of the cruise (stations 1-6), the analysis of CFC-11 could be carried out successfully. From stas. 1-6, only a few samples seem without contamination, which prevented contouring. Thus the stations have been omitted in drawing the zonal CFC section through the Algerian Basin. Calibration was done with standard gas provided by D.Wallace, Pacific Marine Environmental Laboratory, and the concentrations are reported in the Scripps Institution of Oceanography 1993 (SIO93) scale. The CFC-11 accuracy was checked by analyzing about 120 water samples twice, and discrepancies were found to be less than $1 \%$. The quality of the CFC-12 data was lower, the analysis being affected by an unknown substance with a similar retention time as CFC-12. The conditions deteriorated seriously after November 2. During these periods, the CFC-12 accuracy was $3-5 \%$. Therefore we present the CFC-11 data from the cruise.

\subsection{Helium}

About 200 helium samples were collected during the cruise. At sea these were filled into clamped-off copper tubing. The gas content of the samples $(40 \mathrm{~mL})$ was vacuum extracted in the laboratory and transferred into glass ampoules. Measurements of helium isotopes $\left({ }^{3} \mathrm{He}\right.$ and $\left.{ }^{4} \mathrm{He}\right)$ and neon were performed using a fully automated mass spectrometric system. Air aliquots were used for instrument calibration and to monitor sensitivity changes. Standard deviations are $0.3 \%$ for helium and $0.2 \%$ for $\delta^{3} \mathrm{He}$ and the $\mathrm{He} / \mathrm{Ne}$ ratio [Well, 1995; Roether et al., 1998]. In general, the helium samples have to be corrected for ${ }^{3} \mathrm{He}$ accumulation from tritium decay during storage, but the storage time was sufficiently small (130 days), so that the effect can be ignored.

\subsection{Tracer Background}

During the past several decades the atmosphere and upper ocean have been tagged with anthropogenic CFCs that had previously not existed in the environment. The CFC atmospheric concentrations increased exponentially until the mid 1970 s, and after 1975 the increase was linear. Since about 1990 the values have remained near constant. The CFCs are introduced into the oceanic mixed layer by air-sea gas exchange, and the equilibrium concentration in surface water is mainly dependent on the atmospheric CFC load and the water temperature. The higher the atmospheric concentration and the colder the water, the higher is the $\mathrm{CFC}$ value in surface water that is in equilibrium with the atmospheric concentration. The CFC signal is transferred into the deep ocean in regions of deep water formation such as the Gulf of Lions in the western Mediterranean [Rhern, 1995].

The main source for helium in the ocean is the atmosphere, with the exchange taking place at the air-sea interface, which drives the isotopic ratio of ${ }^{3} \mathrm{He} /{ }^{4} \mathrm{He}$ toward a solubility equilibrium with the atmosphere. A few percent oversaturation of $\mathrm{He}$ in the mixed layer are commonly observed and are due to air injection from bubbles [Crang and Weiss, 1971]. In the ocean interior the isotopic ratio is altered by processes that have their source in the ocean, namely, radiogenic decay of tritium and release of helium on the ocean floor. Subsurface decay of tritium leads to accumulation of excess ${ }^{3} \mathrm{He}$, the 
magnitude of which depends on the combined effect of the tritium levels and the subsurface storage times. The tritiugenic ${ }^{3} \mathrm{He}$ production is most significant in the upper water column and elevates ${ }^{3} \mathrm{He} /{ }^{4} \mathrm{He}$ ratios above solubility equilibrium values [Jenkins, 1987; Roether et al., 1998]. A small contribution of helium is added at the ocean floor, the so-called "terrigenic" helium. Depending on the source of the terrigenic helium, its isotopic composition varies considerably. Terrigenic helium originating from the Earth's mantle exhibits an order of magnitude higher ${ }^{3} \mathrm{He}$ concentration than air. The release of mantle helium into the ocean occurs on mid-ocean ridges [Lupton and Craig, 1981] or by volcanoes. In the Mediterranean the terrigenic helium is largely due to alpha decay in the Earth's crust and sediment [Roether et al., 1994]; such helium is 1 order of magnitude lower in ${ }^{3} \mathrm{He}$ than air. Investigations in the eastern Mediterranean have shown substantial levels of terrigenic helium predominately from the crust and sediments with only a small (5\%) contribution of mantle helium [Roether et al., 1998]. In areas of active volcanism the conditions might differ.

Atmospherically derived helium is dominating the distributions within the water, but the far more interesting property for studying interior processes within the ocean is the helium from the internal sources. Separating these components is generally difficult, but a method using neon measurements has been developed to separate the atmospheric influence from the interior source [Roether et al., 1998]. It makes use of the fact that, while neon is subject to the same changes as helium in the mixed layer, it does not have any interior sources. The neon concentration therefore depends only on mixed-layer processes. Details of the computation of non atmospheric helium, which still contains both the terrigenic and the tritiugenic part, are given by Roether et al. [1998].

\subsection{Lowered Acoustic Doppler Current Profiler (LADCP)}

The LADCP attached to the CTD rosette system provides a full ocean depth profile of horizontal currents. The LADCP records overlapping profiles of vertical shear of horizontal velocity, which are averaged to form a full ocean depth shear profile. The shear profile is integrated vertically to obtain the baroclinic velocity component. The vertically integrated shear profiles are then made absolute by referencing them to the total instrument displacement, using a combined Global Positioning System - Global Navigation Satellite System (GPS-GLONASS) positioning system, which is more accurate $(16 \mathrm{~m})$ than the GPS system without military accuracy $(100 \mathrm{~m})$. The data were processed according to Fischer and Visbeck [1993]. Twice, the LADCP had to be opened to replace the batteries and then failed to give good data. After retesting and checking, the LADCP performed normally again, so that only a few velocity profiles (stations 3-6 and 40-43) were lost.

\subsection{Deep Lagrangian Floats}

Profiling deep floats were deployed at various locations in the Algero Provençal Basin. The instrument design, called SOLO, is a new generation of $\mathrm{Au}$ tonomous Langrangian Circulation Explorer (ALACE) floats [Davis et al., 1992] and is built at Scripps Institution of Oceanography. The units were programmed to drift at a depth of $1200 \mathrm{~m}$ for 7.5 days during each dive, followed by a surface interval of 12 hours. During that interval the positions were determined via the ARGOS data location system typically 4-8 times and the profile data (temperature only) were transmitted. During the surface intervals, floats located near a boundary frequently drifted into regions with water depths less than $1200 \mathrm{~m}$ for extended periods. Since they must have been grounded during these times, the trajectories and velocities are not significant.

\section{Tracer Distributions}

\subsection{Vertical Profiles}

Figure 2 shows CFC-11 and salinity profiles from the Algero-Provençal and the Tyrrhenian basins. The CFC11 profiles in both basins show a maximum around 50$100 \mathrm{~m}$, which is the remnant of the winter mixed layer (lower temperatures imply higher equilibrium concentrations), also characterized by a salinity and a temperature minimum. The salinity maximum of the LIW at about $350 \mathrm{~m}$ depth has no recognizable CFC signal. However, closer to the formation region in the eastern Mediterranean, the LIW shows a CFC maximum or at least small vertical gradients around $300 \mathrm{~m}$ [Roether and Schlitzer, 1990], which erodes by mixing with adjacent water masses.

The CFC-11 profiles in the Algero-Provençal Basin reach a minimum $\left(0.6-0.9 \mathrm{pmol} \mathrm{kg} \mathrm{kg}^{-1}\right)$ in depths around 900-1300 m. Below this depth a linear increase is observed to $2000 \mathrm{~m}$. The highest CFC values at this level of $2000 \mathrm{~m}$ depth are found in the Gulf of Lions. In the depth range below, the values remain constant with depth and have no horizontal gradients. The mean CFC-11 concentration in the Algero-Provençal Basin below $2100 \mathrm{~m}$ was $1.01 \pm 0.02 \mathrm{pmol} \mathrm{kg}^{-1}$ (104 measurements). As discussed by Rhein [1995], the high deep water concentrations of the WMDW are caused by deep convection in the Gulf of Lions, whereas the CFC minimum at 900-1300 $\mathrm{m}$ depth cannot be produced in the Gulf of Lions but has to be advected from outside the convection region. The actual source of the CFC minimum, however, remained unclear until now.

In the Tyrrhenian Sea the CFC concentrations decrease monotonically with depth below the near-surface maximum and are generally lower than in the AlgeroProvençal Basin, with a mean concentration of $0.58 \pm$ $0.06 \mathrm{pmol} \mathrm{kg}^{-1}$ below $1000 \mathrm{~m}$ (50 measurements). An important exception is the CFC increase just above the bottom, present in the southern stations. The salinity and temperature of the deep water in the Tyrrhe- 

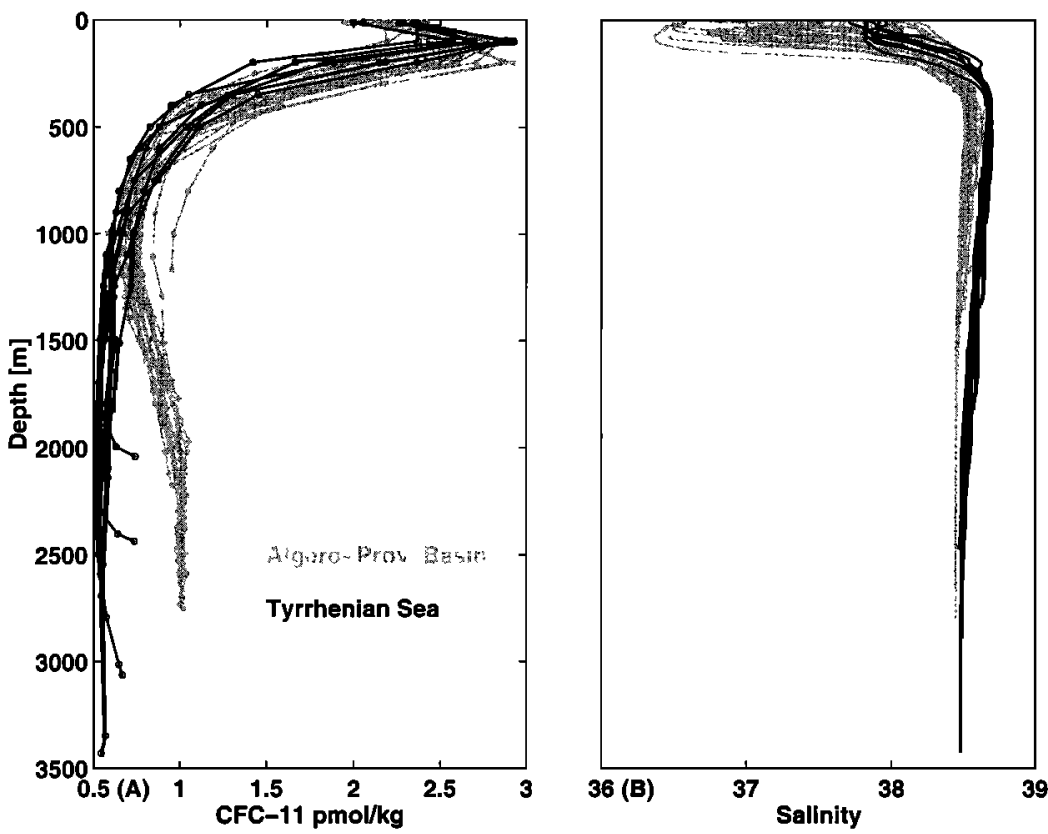

Figure 2. (a) CFC-11 and (b) salinity profiles in the Algero-Provençal Basin (shaded) and the Tyrrhenian Basin (solid), Data are from the R/V Poseidon cruise 234, autumn 1997.

nian are higher than in the WMDW, and the density at $2500 \mathrm{~m}$ depth in the Tyrrhenian $\left(\sigma_{2}=37.753\right)$ is lower than that in the Algero-Provençal Basin $\left(\sigma_{2}=37.760\right)$. This implies that the inflowing WMDW will remain close to the bottom of the Tyrrhenian Sea.

Figure 3 shows selected profiles of non atmospheric ${ }^{3} \mathrm{He}$ from the Algero-Provençal Basin and the Tyrrhenian Basin. All profiles show a maximum in about $500 \mathrm{~m}$ depth due to ${ }^{3} \mathrm{He}$ production from tritium decay, which occurs mostly in the upper layers.

The maximum is strongest in the Tyrrhenian Basin and could indicate longer storage time. In the depth range below the maximum the profiles start to diverge, and they are distinctly different in the deep water range below $1500 \mathrm{~m}$. Higher values $(14 \%)$ are found in the Tyrrhenian Basin, and the pronounced excess in ${ }^{3} \mathrm{He}$ is probably due to local addition of mantle helium from volcanoes. Deep submarine gas vents have been observed in the Tyrrhenian Basin in the vicinity of the Aeolian Islands [G. Etiope, personal communication, 1998] and there are probably other sites within the basin as well. A tritiugenic contribution to the elevated ${ }^{3} \mathrm{He}$ should be small since tritium concentrations decrease with depth. Far lower values of non atmospheric helium (10\%) are found in the Algero-Provençal Basin, indicating a different environment. Active deep water formation within this basin and the involved mixing of the water column incorporate water with low non atmospheric ${ }^{3} \mathrm{He}$ from upper layers and tend to create a decrease toward the deep water. Profiles from stations close to Sardinia and Corsica are intermediate between the Algero-Provençal Basin and the Tyrrhenian Basin at depths between 700 and $1500 \mathrm{~m}$ and converge with those found in the Algero-Provençal Basin below. The latter would indicate that the deep water within the Algero-Provençal Basin is the same at these profiles.

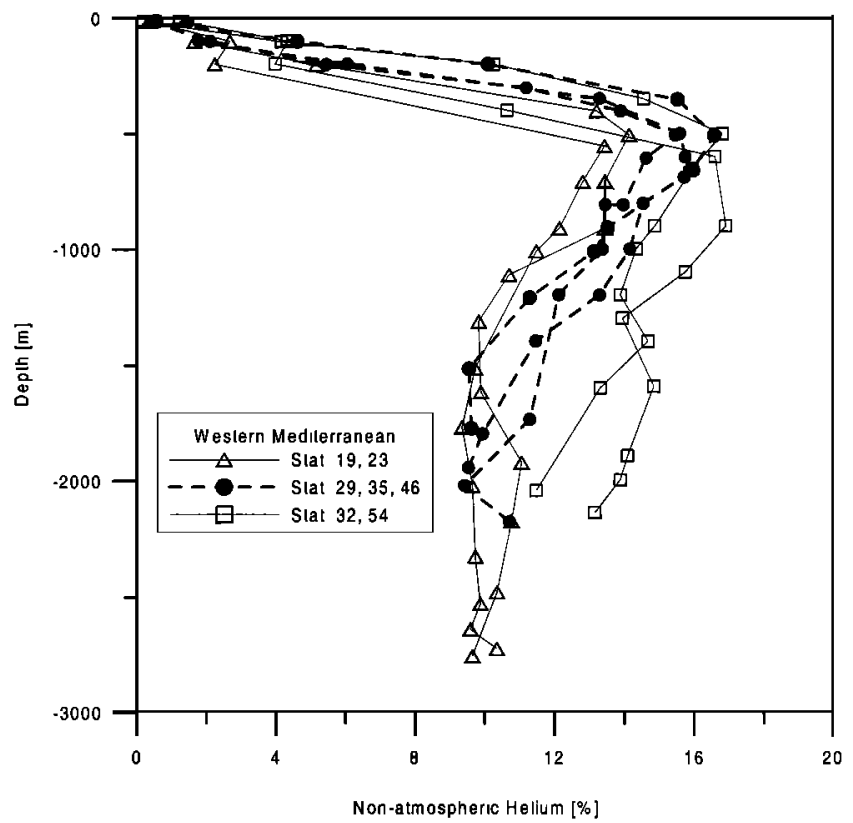

Figure 3. Selected profiles of non atmospheric ${ }^{3} \mathrm{He}$ from the Algero-Provençal Basin and Tyrrhenian Basin. Stations 32 and 54 are in the southern Tyrrhenian, stations 29,35 , and 46 lie along the west coast of Sardinia and Corsica, while stations 19 and 23 are from the interior Algero-Provençal Basin (also see Figure 1). 


\subsection{Tracer Distributions}

3.2.1. Tyrrhenian Sea. The meridional CFC-11 section through the Tyrrhenian Sea (Plate 1a) shows a downsloping of the CFC-11 contours from south to north for depths greater than $800 \mathrm{~m}$. At about $2200 \mathrm{~m}$, these meridional gradients cause a decrease from $>0.7$ pmol kg ${ }^{-1}$ at the southern Tyrrhenian Sea to $0.58 \mathrm{pmol}$ $\mathrm{kg}^{-1}$ north of $40^{\circ} \mathrm{N}$. The CFC maximum in the bottom layer is evident south of $40^{\circ} \mathrm{N}$ and most prominent at the locations close to the Tyrrhenian Trough. These high CFC values are associated with the lowest salinities $(<38.48)$ observed in the deep and intermediate waters (Figure 4a), which indicates that the source is WMDW.

3.2.2. Algero-Provençal Basin. Plate $1 \mathrm{~b}$ shows a zonal CFC section through the Algero-Provençal Basin near $38^{\circ} \mathrm{N}$. The most prominent feature is the CFC minimum between 900 and $1300 \mathrm{~m}$ depth. The concentrations in the minimum are lowest close to the Sardinian coast and increase farther to the west. This mirrors closely (but with the opposite sign and at larger depths) the known distribution of salinity in the LIW and down to $1600 \mathrm{~m}$, which is highest near Sardinia (Figure 4b). The CFC minimum originates in the Tyrrhenian Sea, as will be shown below, and thus is the unique signature of the TDW in the Algero-Provençal Basin. The deep water below about $2000 \mathrm{~m}$ is rather uniform in CFCs and salinity, with negligible east-west gradients (Plate $1 \mathrm{~b}$ and Figure $4 \mathrm{~b}$ ). The meridional CFC-11 section from the Algerian Basin to the Gulf of Lions (not shown) shows the same features: a CFC-11 minimum around $900-1300 \mathrm{~m}$, a CFC- 11 increase down to $2000 \mathrm{~m}$, and constant values below.

\section{Discussion}

\subsection{TDW Import Into the Algero-Provençal Basin}

As already pointed out by Hopkins [1988] and Astraldi and Gasparini [1996], the $\Theta-S$ characteristics of the TDW do not allow one to detect its presence in the Algero-Provençal Basin, because its features could also be a local mixing product. The CFC distributions, however, are a unique tool for documenting the horizontal and vertical extent of the TDW in the Algero-Provençal Basin.

The horizontal distribution of CFC in the CFC minimum layer (Figure 5) shows three different regimes: CFC values lower than $0.7 \mathrm{pmol} \mathrm{kg}^{-1}$ (solid circles) are restricted to the Tyrrhenian Sea and the Sardinian and Corsican coast of the Algero-Provençal Basin. The highest values ( $>0.75 \mathrm{pmol} \mathrm{kg}^{-1}$, pluses, open circles) are found off Toulon and Menorca and east of $2^{\circ} \mathrm{E}$. Values greater than $0.8 \mathrm{pmol} \mathrm{kg}{ }^{-1}$ are found east of $2^{\circ} \mathrm{E}$ (open circles), with the maximum near the Spanish coast. We do not know if the elevated CFC levels east of $2^{\circ} \mathrm{E}$ are related to the arrival of water formed in February-March 1997 in the Gulf of Lions by convection or to the dynamics in the Alboran Sea. The central Algero-Provençal Basin exhibits intermediate values between 0.7 and $0.75 \mathrm{pmol} \mathrm{kg}^{-1}$ (stars).
The variation and range of water mass properties of the CFC minimum layer in the Algero-Provençal Basin can be explained as a mixture between deep water from the Tyrrhenian and the WMDW generated in the Algero-Provençal Basin. This is visible in the CFC11/salinity diagram (Figure 6), where the values from the 800-1500 $\mathrm{m}$ depth range in the Algero-Provençal Basin lie on a mixing line between the TDW in the Tyrrhenian Sea from 900-1500 $\mathrm{m}$ depth and the CFC11 /salinity values of the $1600-1700 \mathrm{~m}$ depth range in the central Algero-Provençal Basin. This also supports an export of TDW into the Algero-Provençal Basin in the depth range between 900 and $1600 \mathrm{~m}$.

As previously mentioned the non atmospheric ${ }^{3} \mathrm{He}$ profiles show a pronounced gradient between 700 and $1500 \mathrm{~m}$ from highest values in the Tyrrhenian Basin to intermediate ones around Sardinia and Corsica to lowest values in the Algero-Provençal Basin. This indicates an outflow of water from the Tyrrhenian Basin into the Algero-Provençal Basin and mixing with ambient waters. It cannot be concluded from the helium profiles alone that a source of mantle helium in the vicinity of Sardinia and Corsica is responsible for the intermediate nature of these profiles, but the correlation with the CFC profiles that do not have interior sources makes this unlikely. The inflow of WMDW into the Tyrrhenian Basin could be responsible for the observed decrease of non atmospheric helium in the bottom layer of station 54 .

The presence of the absolute middepth CFC minimum zone everywhere in the Algero-Provençal Basin, the horizontal distribution of its characteristics, and the similarity between the observations near the Sardinian and Corsican coast with the data in the Tyrrhenian Sea, taken together with the helium observations, lead us to the conclusion that the Tyrrhenian Sea is the origin of the middepth CFC minimum in the Algero-Provençal Basin. The horizontal distribution of the CFC concentrations in the minimum layer in the Algero-Provençal Basin (Figure 5) reflects the general cyclonic circulation, but the occasional anomalies found are also suggestive of additional eddy activity, which would then transport the characteristics of the boundary current into the interior. The distribution of water mass characteristics is therefore the result of advection and mixing, integrated over various time and space scales.

The data available to date from the seven Lagrangian floats in the TDW clearly support this picture (Figure 7). A weak but well-defined cyclonic boundary circulation is found with typical speeds of a few centimeters per second. In the interior a pronounced eddy activity is found, with speeds that are generally larger than the boundary flow. There is no systematic interior circulation detectable; however, large translation across substantial parts of the basin occur on the timescale of a few months. This flow field must lead to appreciable stirring of water mass properties, which could explain the smooth variation of the tracer and salinity distributions away from the boundary circulation.

The TDW circulation observed with LADCPs during the R/V Poseidon 234 cruise (Figure 8 ) can only reflect 
a)

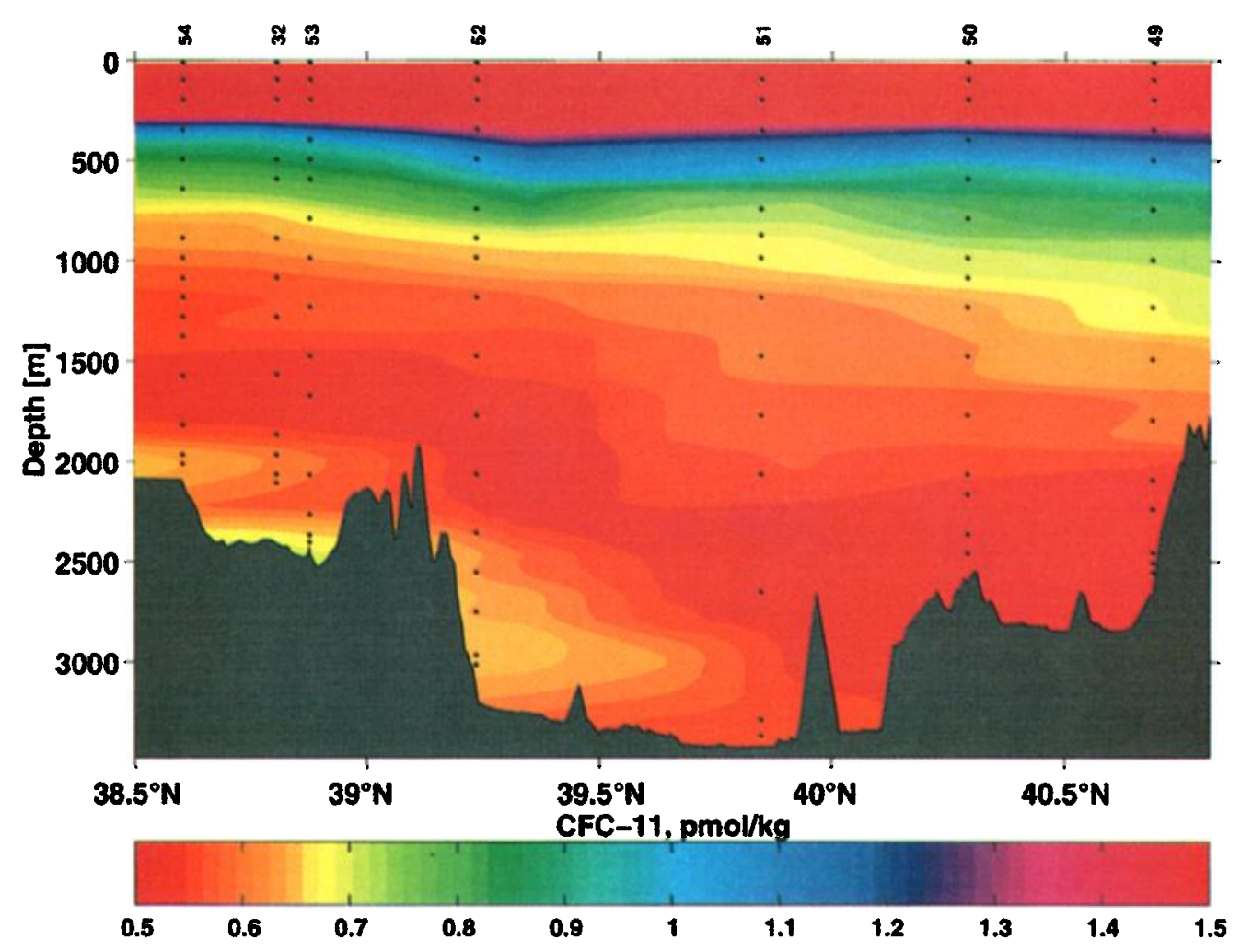

b)

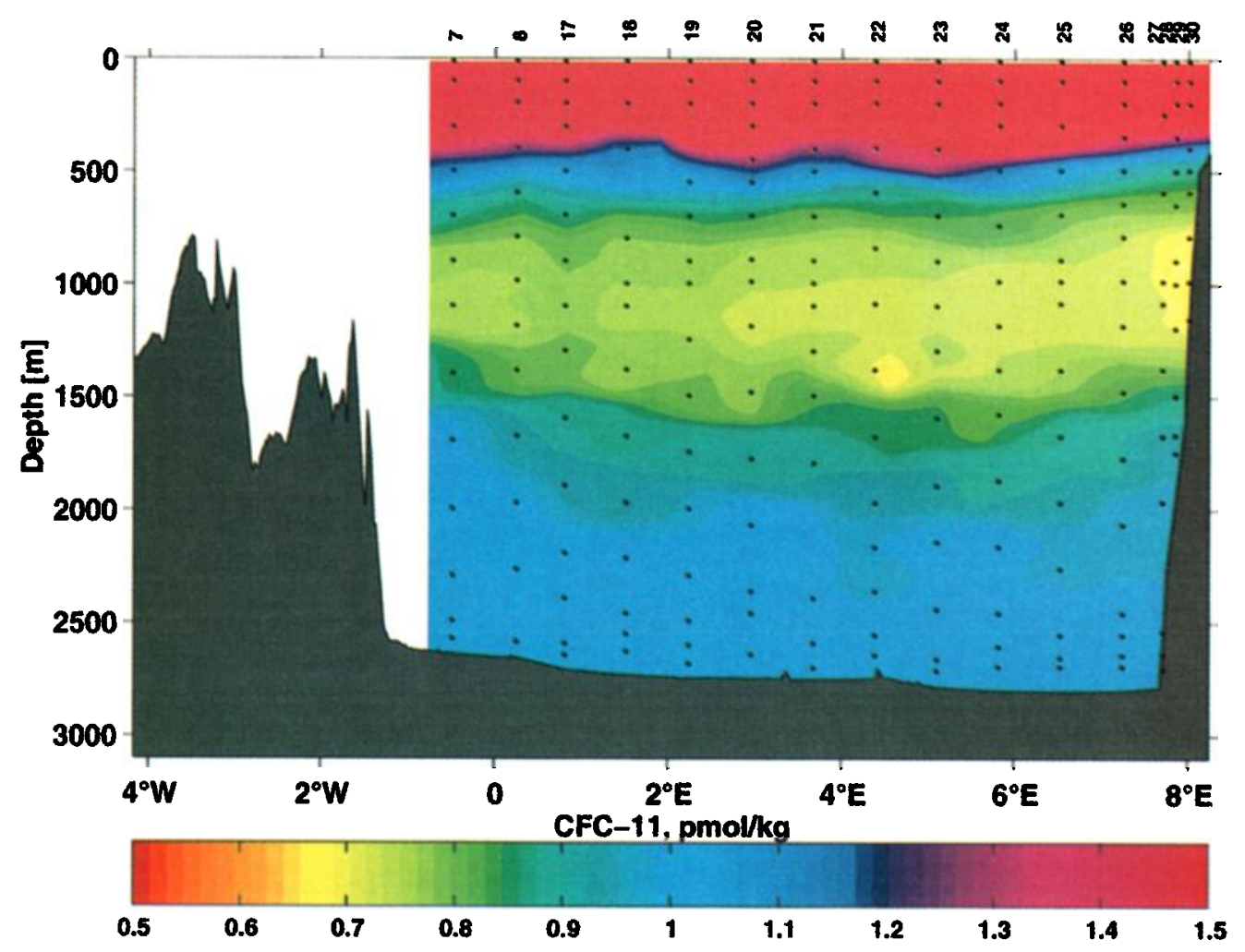

Plate 1. CFC-11 sections (a) in the Tyrrhenian Sea and (b)along approximately $38^{\circ} \mathrm{N}$ in the Algero Provençal Basin. For location of the profiles, see Figure 1. Color scales are chosen to emphasize the deep CFC-11 distributions. 

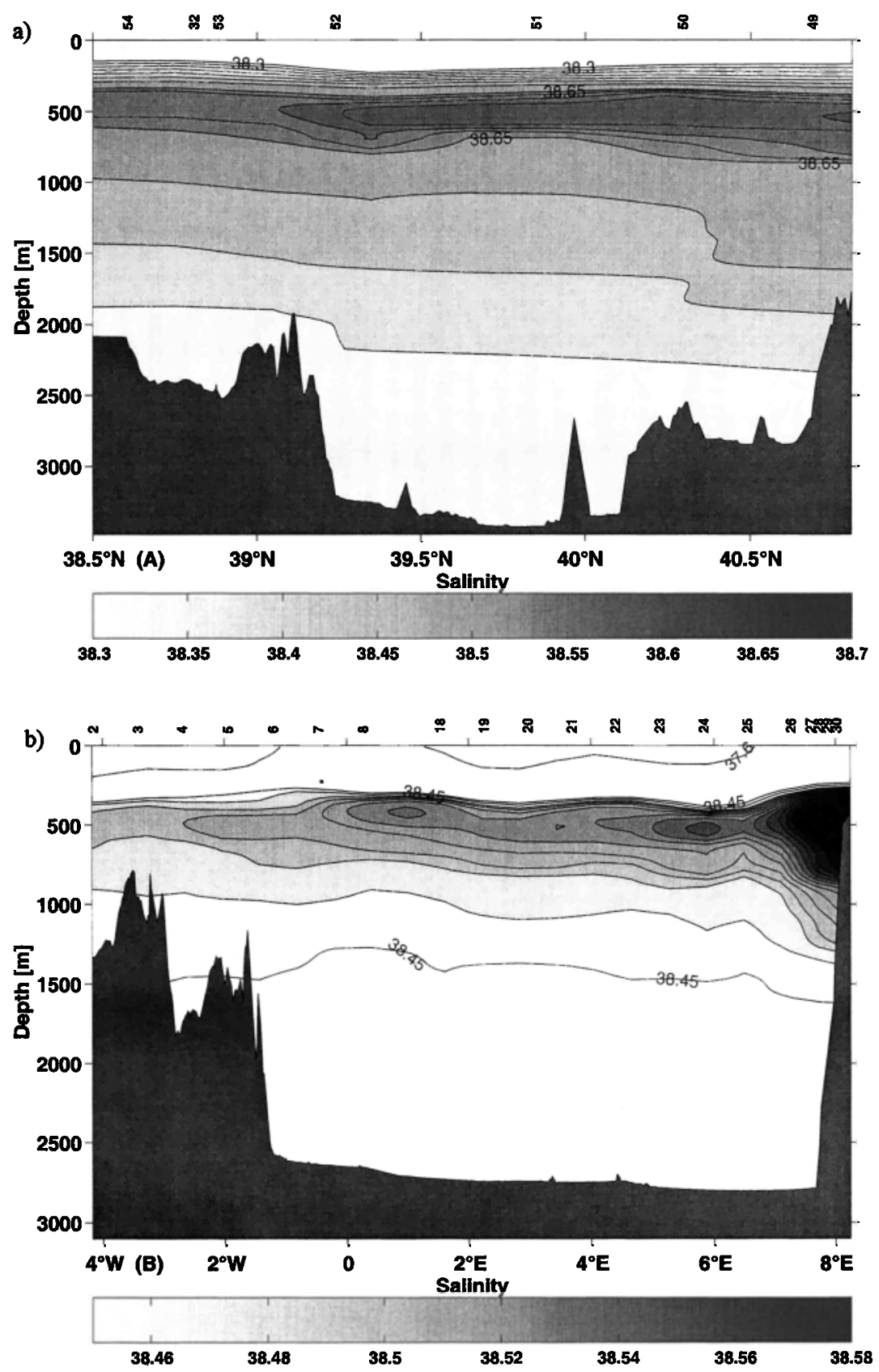

Figure 4. Salinity sections (a) in the Tyrrhenian Sea and (b) along approximately $38^{\circ} \mathrm{N}$ in the Algero Provençal Basin (b). For location of the profiles, see Figure 1.

an instantaneous snapshot of the circulation. The spatial distribution of the velocity profiles was too coarse to resolve the eddy field present in the interior of the Algero-Provençal Basin during the cruise, leaving us with an incomplete view of the flow field. Boundary currents with mean velocities of $5-10 \mathrm{~cm} \mathrm{~s}^{-1}$ are found southwest of Sardinia and at $0^{\circ} \mathrm{E}$ at the Spanish coast. The boundary sections farther north have lower velocities. The mean direction at the Menorca section (stations 60-65; see Figure 1) is toward the west and not eastward as would be expected in the mean. However, the velocities $\left(10 \mathrm{~cm} \mathrm{~s}^{-1}\right)$ in the southern Algero-
Provençal Basin south of $38^{\circ} \mathrm{N}$ and east of $2^{\circ} \mathrm{E}$ are as high as in the boundary current off Sardinia, and they are directed toward the Alboran Sea. Preliminary results from earlier work by Millot [1987a,b] suggested that there is no direct flow path into the Alboran Sea but that the flow occurs in eddies. Our present database (floats and LADCP) is not large enough yet to give a clear answer on that issue.

The fate of the TDW in the Algero-Provençal Basin thus has various aspects. It enters from the Tyrrhenian and flows cyclonically as a boundary current around the basin, from where it is mixed into the interior via eddy 


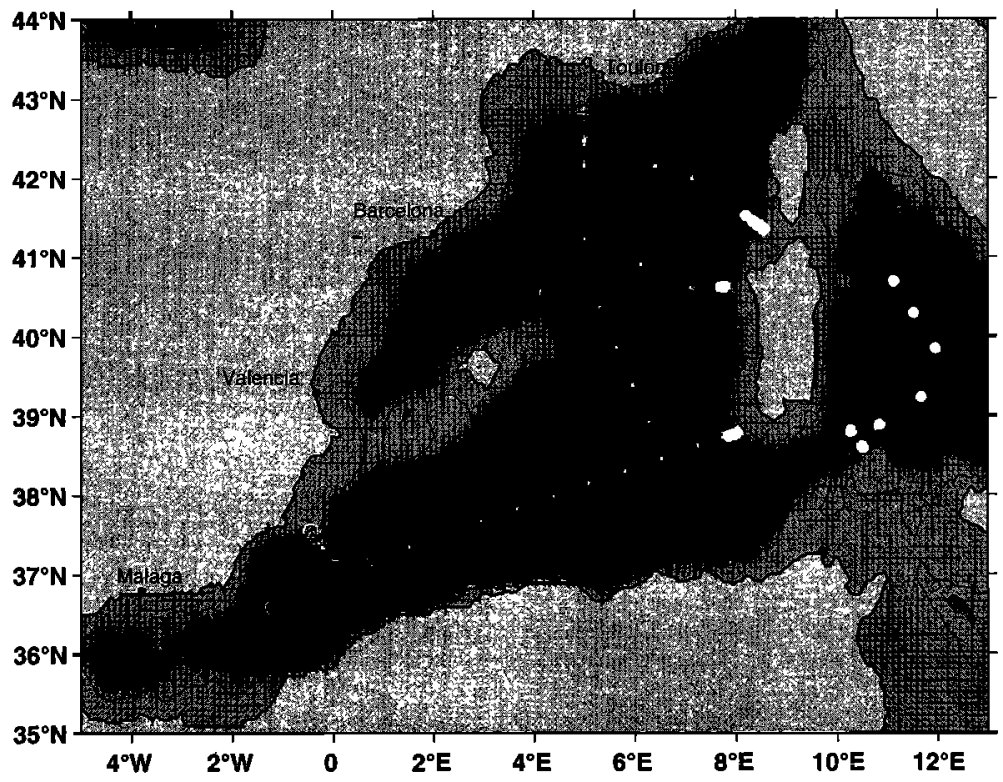

Figure 5. Horizontal distribution of the CFC minimum $\left(\sigma_{1}=33.465-33.480\right)$. Symbols denote the following: solid circles, CFC concentrations $<0.7 \mathrm{pmol} \mathrm{kg}{ }^{-1}$; stars, $0.7-0.75 \mathrm{pmol} \mathrm{kg}^{-1}$; pluses, $0.75-0.80 \mathrm{pmol} \mathrm{kg}^{-1}$; and open circles, $>0.8 \mathrm{pmol} \mathrm{kg}^{-1}$

stirring. As a result, it occupies a large volume of what would be considered deep water in the Algero-Provençal Basin. Deep convection in the Gulf of Lions occasionally erodes the CFC minimum in this layer, mixing some TDW into the deeper layers and, at the same time, injecting fresh CFC into the minimum zone. The TDW, modified by these two processes, then partly contributes to the outflow through the Strait of Gibraltar and partly recirculates into the Tyrrhenian Sea. The water flowing into the Tyrrhenian Sea thus consists of the modified TDW and of the gradient zone between the TDW and WMDW with higher CFC concentrations, the latter of which is responsible for the CFC increase in the southern Tyrrhenian Sea above the bottom.

\subsection{Water Mass Modification in the Tyrrhenian Sea}

As in the investigations of Hopkins [1988], the salinity and CFC-11 concentrations and spatial distributions in the deep Tyrrhenian Sea lead to the conclusion that the tracer signal, especially the increase of CFC11 in the bottom layer in the southern Tyrrhenian, is caused by the inflow of WMDW through the Tyrrhenian Trough. The density at the sill depth in the AlgeroProvençal Basin is around $\sigma_{1}=33.481\left(\Theta=12.792^{\circ} \mathrm{C}\right.$, $\mathrm{S}=38.445)$ the density of the TDW in the Tyrrhenian Basin below the sill depth is between $\sigma_{1}=33.479$ and $\sigma_{1}=33.481$, and therefore the inflow is expected to sink below the TDW as is, in fact, observed in our sections (e.g. Plate 1a and Figure 4a).

The hydrographic characteristics of the TDW in the Tyrrhenian Sea show that it is a mixing product of the inflowing WMDW and the LIW above it (see section 3.2.1). We will show below that this mixing (over the large depth range of $900-1600 \mathrm{~m}$ ) occurs on a 10 to 20 year timescale. Zodiatis and Gasparini [1996] showed that the required mixing cannot occur in the interior of the basin, which is covered by thermohaline staircases. The major part of the LIW-TDW exchanges seems to take place near the boundaries, where the LIW, after entering the Tyrrhenian Sea, sinks to $1800 \mathrm{~m}$ depth and continues to flow very close to the boundaries. The horizontal shear between the boundary current and the interior circulation could play an important role in transferring heat and salt into the central part of the basin [Zodiatis and Gasparini, 1996]. Owing to lack of mea-

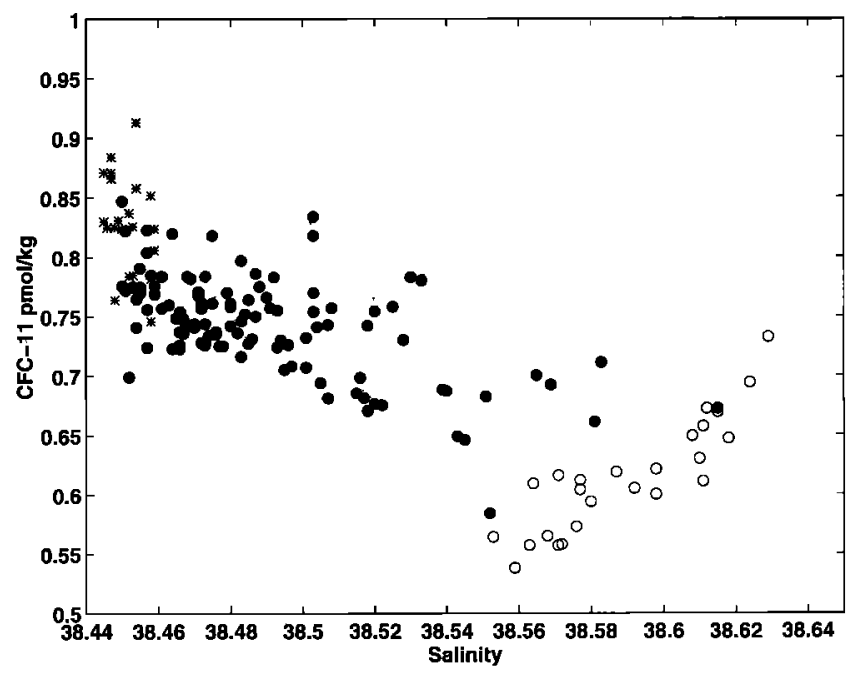

Figure 6. CFC-11/salinity characteristics in the Tyrrhenian Sea, $900-1500 \mathrm{~m}$ (open circles), Algero Provençal Basin, 800-1500 m depth (solid circles), and Algero Provençal Basin, 1600-1700 m depth (stars). 


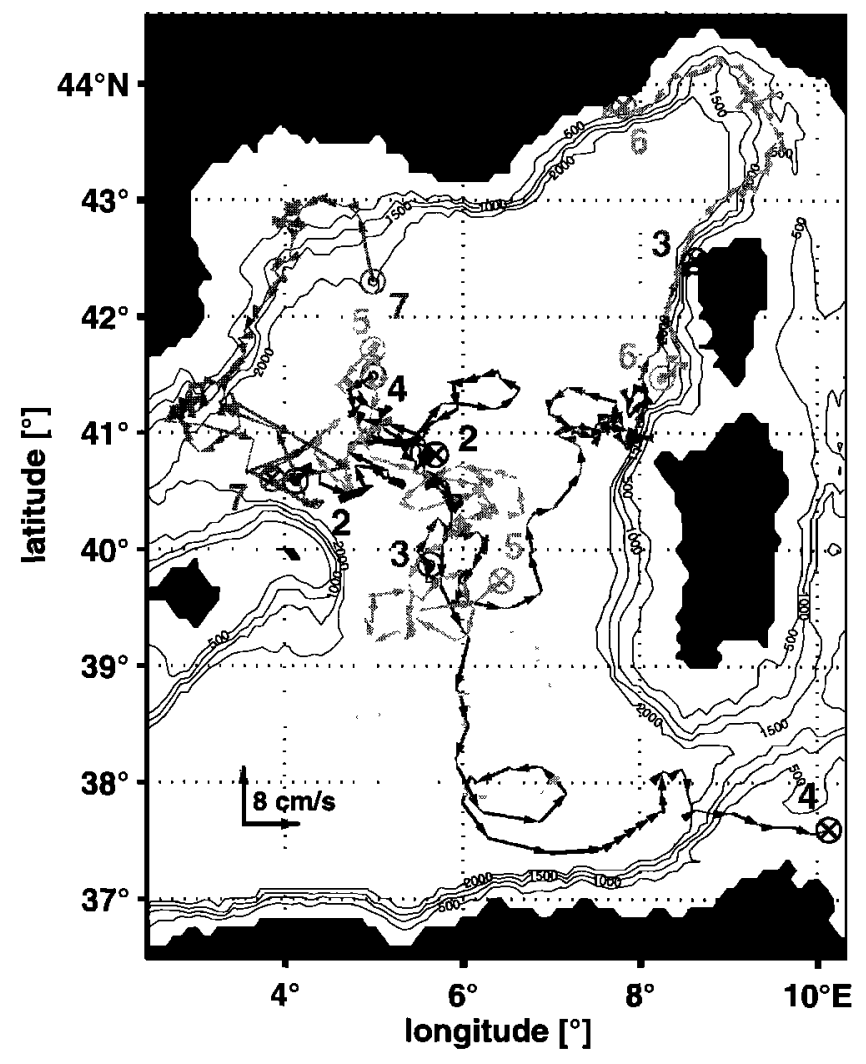

Figure 7. Displacements of floats deployed in October 1997 drifting at a depth of $1200 \mathrm{~m}$, which corresponds closely to the core of the TDW water mass in the Algero-Provençal Basin. Floats 1,2,4, and 6 were recovered or terminated their mission earlier. Each arrow shows the displacement during the approximately 7.5 days of submersion. The thin lines correspond to the surface drift. The open circles denote the deployment location; the cross denotes the last position of the float. For reference, the displacement corresponding to $8 \mathrm{~cm} \mathrm{~s}^{-1}$ is included. Note that while at the surface, the floats located near a boundary frequently drift into regions shallower than $1200 \mathrm{~m}$.

surements at the boundaries we could only estimate the efficiency of three other processes that might contribute to this mixing: deep convection, mixing by heat flux from the bottom, and double-diffusive processes.

In order to examine if deep water formation via deep convection could occur in this region, we compared local values for the vertically integrated buoyancy content and the buoyancy loss due to surface fluxes for a typical winter. For the calculation of the vertically integrated buoyancy we use data both from our CTD measurements in November 1997 and from two T-S climatologies of the western Mediterranean Sea [Brasseur et al., 1996, Krahmann, 1997]. To estimate the winterly buoyancy loss, we use climatological values derived from the Comprehensive Ocean - Atmpshere Data Set (COADS) by Da Silva et al., [1994]. The resulting values are summarized in Table 1 , which includes, for comparison, equivalent results for the Gulf of Lions, a well-known deep convection region. MED5, THETIS, and Da Silva denote values derived from Brasseur et al. [1996], Krahmann, [1997] and Da Silva et al. [1994], respectively.

According to these calculations, the typical buoyancy that the Tyrrhenian loses during a winter (November February) is $0.5 \pm 0.5 \mathrm{~m}^{2} \mathrm{~s}^{-2}$. At the beginning of winter the buoyancy content of just the upper $200 \mathrm{~m}$ is on the order of $1 \mathrm{~m}^{2} \mathrm{~s}^{-2}$, and for the upper $1750 \mathrm{~m}$ we obtain values much larger. Therefore, in the Tyrrhenian Sea, the buoyancy loss by surface fluxes is only sufficient to allow mixing down to less than $200 \mathrm{~m}$, thus excluding convection as a source for changes in deep Tyrrhenian water mass characteristics.

Another mechanism that might encourage the imported WMDW in the Tyrrhenian Basin to mix with overlying water masses is the buoyancy gain through heat flow from the bottom. Detailed heat flow surveys in the Algero-Provençal Basin and the Tyrrhenian Basin showed mean heat flows between $90-150 \mathrm{~mW} \mathrm{~m}^{-2}$ [Hutchison et al., 1985]. In the central Tyrrhenian Sea the vertically integrated buoyancy (start of the integration is the bottom) in the lowest $1000 \mathrm{~m}$ of the 1997 CTD profiles is zero, which is expected if convection due to warming from the bottom occurs in this layer. On top of this layer a gradient zone of the integrated buoyancy was found, with an increase of $0.1 \mathrm{~m}^{2} \mathrm{~s}^{-2}$ in a $750 \mathrm{~m}$ thick layer. A heat flow of $100 \mathrm{~mW} \mathrm{~m}^{-2}$ from the bottom would lead to a growth by entrainment of the convecting layer by about $12 \mathrm{~m}$ in a year. Since the stratification is expected to remain in a steady state (compensated by advective fluxes), we do not believe this process can contribute significantly to the mixing over hundreds of meters with the overlying LIW.

Thermohaline staircases (pronounced steps both in temperature and salinity) have been observed in the Tyrrhenian Sea over the past 25 years [Molcard and Tait, 1977; Johannessen and Lee, 1974; Zodiatıs and Gasparini, 1996]. The thermohaline steps are located between the LIW and the underlying TDW. The different diffusivities of temperature and salt allow the release of potential energy stored in the unstable salinity stratification (the LIW has a higher salinity than the TDW). The effective downward flux of salt has been estimated from Zodiatis and Gasparini [1996] to be about $2 \times 10^{-8} \mathrm{~kg} \mathrm{~m}^{-2} \mathrm{~s}$. However, this number is subject to a high uncertainty since the basis for the calculation comes from laboratory experiments that are extrapolated and adjusted to observed oceanic cases [Fleury and Lueck, 1991; Zodiatis and Gasparini, 1996]. We can now estimate whether this vertical flux is of any importance for the exchange of salt between LIW and TDW. Assuming that deep water exchange between the two basins is of the order of $0.2 \mathrm{~Sv}$ [Hopkins, 1988] and multiplying the deep volume transports with the salinity difference between inflowing and outflowing water of about 0.1 and division by the area of the deep Tyyrhenian Sea of $1.75 \times 10^{11} \mathrm{~m}^{2}$ lead to a salt flux of $11.4 \times 10^{-8} \mathrm{~kg} \mathrm{~m}^{-2} \mathrm{~s}$. This means that about $18 \%$ of the salinity exchange is caused by the double-diffusively enhanced vertical fluxes. This gives some support to the 


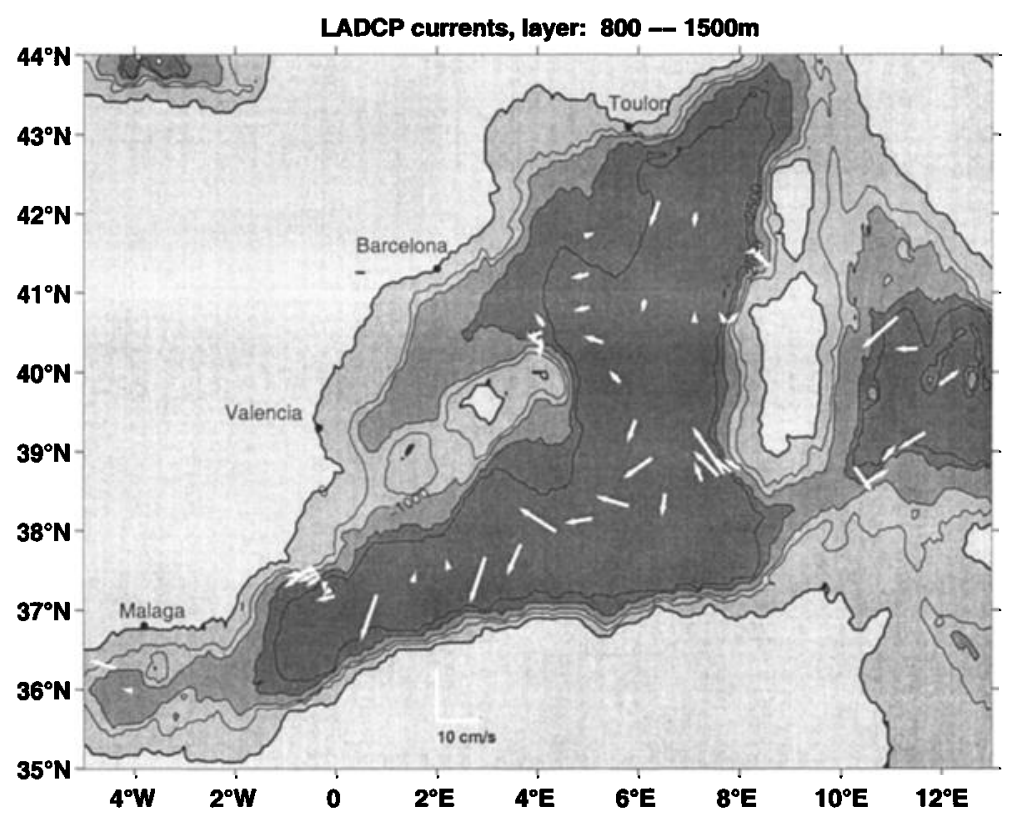

Figure 8. Mean LADCP velocities $\left(\mathrm{cm} \mathrm{s}^{-1}\right.$ ) averaged over 800-1500 $\mathrm{m}$ depth, corresponding to much of the TDW layer in the Algero-Provençal Basin. For profiles with the bottom between 1000 and $1500 \mathrm{~m}$ depth, the mean velocity from $800 \mathrm{~m}$ to the bottom is presented.

result of Zodiatis and Gasparini [1996], that the main mixing occurs near the boundaries.

4.2.1. Role of the deep inflow through the Strait of Sicily. Astraldi et al. [1996] observed that the inflow from the eastern Mediterranean is composed of two water masses all year long, the LIW and a colder and denser water mass than the LIW. However, the $\Theta-S$ characteristic of this water mass $\left(\Theta=13.63^{\circ} \mathrm{C}, \mathrm{S}=38.73\right.$, Figure 9) is not found in our Tyrrhenian Sea data. The data of all Tyrrhenian Sea profiles are located close to the mixing line between the LIW observed in the Strait of Sicily and the bottom water of the Tyrrhenian Sea.
Thus we conclude that the influence of this dense component on the water mass characteristics of the Tyrrhenian Sea is marginal in our data.

4.2.2. Ventilation of the Tyrrhenian Sea. To estimate the ventilation rate of the deep Tyrrhenian Sea with the help of tracers, one has to know the temporal evolution of the CFC signal in all water masses affecting the TDW in that basin. The recipe for calculating the annual CFC concentration in a water mass requires that the conditions during the formation of the water mass are known, that the time between formation and arrival in the Tyrrhenian Sea can be estimated, and that the

Table 1. Vertically Integrated Buoyancy From Climatological and Recent Temperature and Salinity Data for the Tyrrhenian Sea and the Gulf of Lions.

\begin{tabular}{lcc}
\hline & Gulf of Lions & Tyrrhenian Sea \\
\hline \multicolumn{3}{c}{ Buoyancy Integrated } \\
\hline \multicolumn{3}{c}{ Down to $1750 \mathrm{~m}$} \\
Cruise P234, early Nov. & $0.75-1.2$ & $2.0-2.4$ \\
MED5, fall, mid-Nov. & 0.9 & 1.8 \\
THETIS, mid-Nov. & 0.9 & 1.6 \\
MED5, winter (mid-Feb.) & 0.3 & 1.2 \\
THETIS, mid-Feb. & 0.3 & 1.2 \\
Buoyancy Integrated & Down to 200 m \\
Cruise P234, early Nov. & $0.5-1.0$ & $1.1-1.4$ \\
MED5, fall, mid-Nov. & 0.6 & 1.0 \\
THETIS, mid-Nov. & 0.6 & 1.1 \\
MED5, winter, mid-Feb. & 0.1 & 0.3 \\
THETIS, mid-Feb. & 0.2 & 0.4 \\
Integrated Winterly & Buoyancy Fluxes \\
Da Silva, mid-Nov. to mid-Feb. & -0.56 & -0.47 \\
Da Silva, mid-Nov. to end Feb. & -0.67 & -0.54 \\
Da Silva, mid-Nov. to mid-March & -0.73 & -0.57 \\
\hline
\end{tabular}

\footnotetext{
Values are in $\mathrm{m}^{2} \mathrm{~s}^{-2}$.
} 


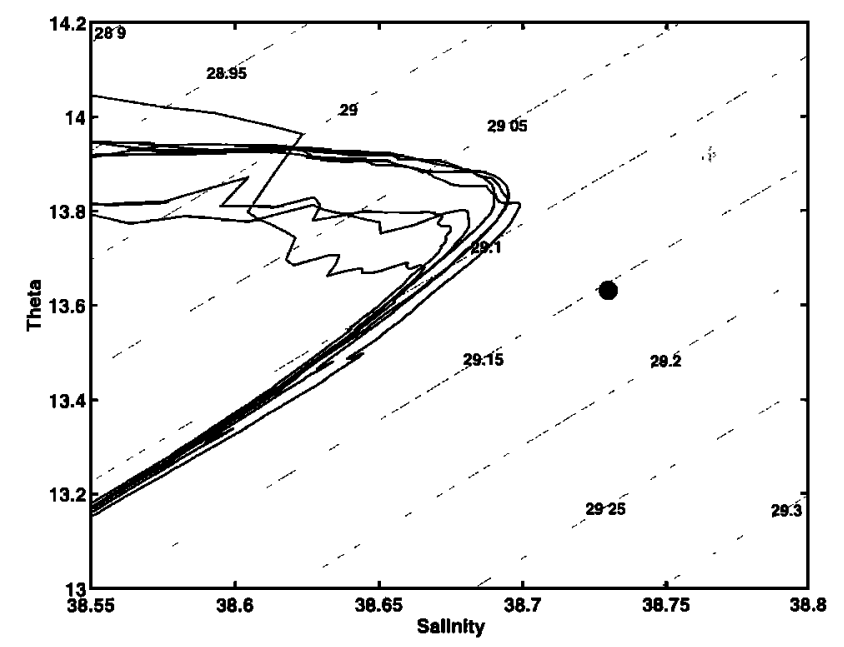

Figure 9. T-S diagram of the Tyrrhenian Sea profiles of the R/V Poseidon 234 cruise. The properties of the LIW inflow at the Strait of Sicily (gray dot) and the densest and coldest water mass in the Strait (dark dot) are indicated; both values are from Astraldi et al. [1996].

mixing with adjacent water masses is either negligible or can be evaluated. Two main water masses ventilate the deep Tyrrhenian Sea: the deep water from the Algero-Provençal Basin intruding through the Tyrrhenian Trough (1900 $\mathrm{m}$ sill depth) and the LIW flowing through the Strait of Sicily.

Some simple approximations can be made for the LIW, because LIW carries no distinct tracer signal. For example, in winter and spring 1991/1992 the CFC profile in the upper $600 \mathrm{~m}$ (i.e., including the LIW) in the Gulf of Lions could be approximated by an exponential fit [Rhein, 1995], where the surface values are in equilibrium with the atmosphere. The same fit also simulates the CFC profiles in the Tyrrhenian Sea, except for the values near the surface, which have lower CFC values in summer owing to higher surface temperatures (Figure 10a). As a result, the history of the vertical profiles is taken to be the winter surface values of the last 50 years multiplied by this exponential shape. Then, the LIW that mixes with the deep water can be described by the time-dependent mean concentrations of the 350$600 \mathrm{~m}$ range, shown in Figure $10 \mathrm{~b}$.

The inflowing water in the depth range between 600 and $1600 \mathrm{~m}$ consists of recirculating TDW and WMDW, and the temporal evolution of the CFC signal of this blend cannot be estimated along the lines used for the LIW. Instead, we assume only that in the combined WMDW and recirulating TDW, the relative changes in the mean CFC concentration with time are proportional to the changes observed during the same period in the surface boundary condition. The relative change is then applied (backward) to the mean CFC values of 1997. This assumption neglects the ventilation timescales of WMDW and TDW in the Algero-Provençal Basin and does not try to resolve the contribution of WMDW or recirculating TDW. To calculate the mean, we av- erage over the central Algero-Provençal Basin profiles in the respective depth range $(600-1900 \mathrm{~m}, \mathrm{CFC}-11=$ 0.80 pmol kg-1 and CFC-12 $=0.44 \mathrm{pmol} \mathrm{kg}^{-1}$ ). The calculated temporal evolution is shown in Figure 10c. Included is the mean CFC-12 concentration for the appropriate depth range from December 1991 [Rhein, 1995], which is consistent with the procedure and assumptions used to establish the curve based on the 1997 value.

In the calculation the deep Tyrrhenian Sea is treated as a well-mixed box, the inflowing water (LIW and inflow from the Algero-Provençal Basin) mixes instanteneously and the exiting water (TDW outflow) equals the volume of the inflowing water masses and has the characteristics of the mixed deep box. Even from the few salinity and CFC profiles taken in the Tyrrhenian Sea, it is clear that the deep Tyrrhenian Sea is not as well mixed as the WMDW below $1900 \mathrm{~m}$ in the Algero-Provençal Basin; but owing to lack of more tracer data, the mean CFC-11 concentration in the Tyrrhenian Sea below $600 \mathrm{~m}$ was calculated at $0.61 \pm$ $0.07 \mathrm{pmol} \mathrm{kg}^{-1}$. The mean CFC value is insensitive to the choice of the upper limit of the deep water. Taking $1000 \mathrm{~m}$ depth as the upper boundary gives an average of $0.58 \pm 0.06 \mathrm{pmol} \mathrm{kg}^{-1}$.

As mentioned previously, the salinity balance in the Tyrrhenian Sea points to a roughly 2:1 mixture of inflowing water from the Algero-Provençal Basin with the LIW [Hopkins, 1988]. To our knowledge, no CFC samples have been analyzed in the Tyrrhenian Sea before 1997 , so we have only one observation to fit the single unknown of the model, the volume of the inflowing water from the Algero-Provençal Basin, assuming a 2:1 mixture of the two water masses. The modeled CFC concentration for the deep Tyrrhenian Sea fits best to the observation in 1997, assuming ventilation times between 10 and 20 years (Figure 10d). Despite the coarse assumptions in the boundary conditions, the model is rather insensitive to changes in the assumptions. Altering the depth range to compute the mean CFC concentration in the LIW, for instance, taking $200-600 \mathrm{~m}$ instead of 350-600 $\mathrm{m}$ to calculate the LIW boundary condition, makes a 2-year change in the ventilation time. Changing the depth range to calculate the average CFC value of the Algero-Provençal Basin inflow from 6001900 to $900-1500 \mathrm{~m}$ also has a marginal effect.

The LIW and inflow from the Algero-Provençal Basin have comparable concentrations, thus changes in the compositions of the mix forming the TDW make no significant difference for the modeled ventilation rate. The modeled ventilation time of $10-20$ years seems rather robust. Taking the volume of the deep Tyrrhenian Sea to be $2 \times 10^{14} \mathrm{~m}^{3}$ and a ventilation time of 15 years, about $0.13 \mathrm{~Sv}$ LIW and 0.26 Sv Algero-Provençal Basin inflow flush the deep water in the Tyrrhenian Sea.

\section{Summary}

The new data set of hydrographic, tracer, LADCP, and deep float observations enabled us to identify and track the Tyrrhenian Sea outflow in the Algero Provençal 

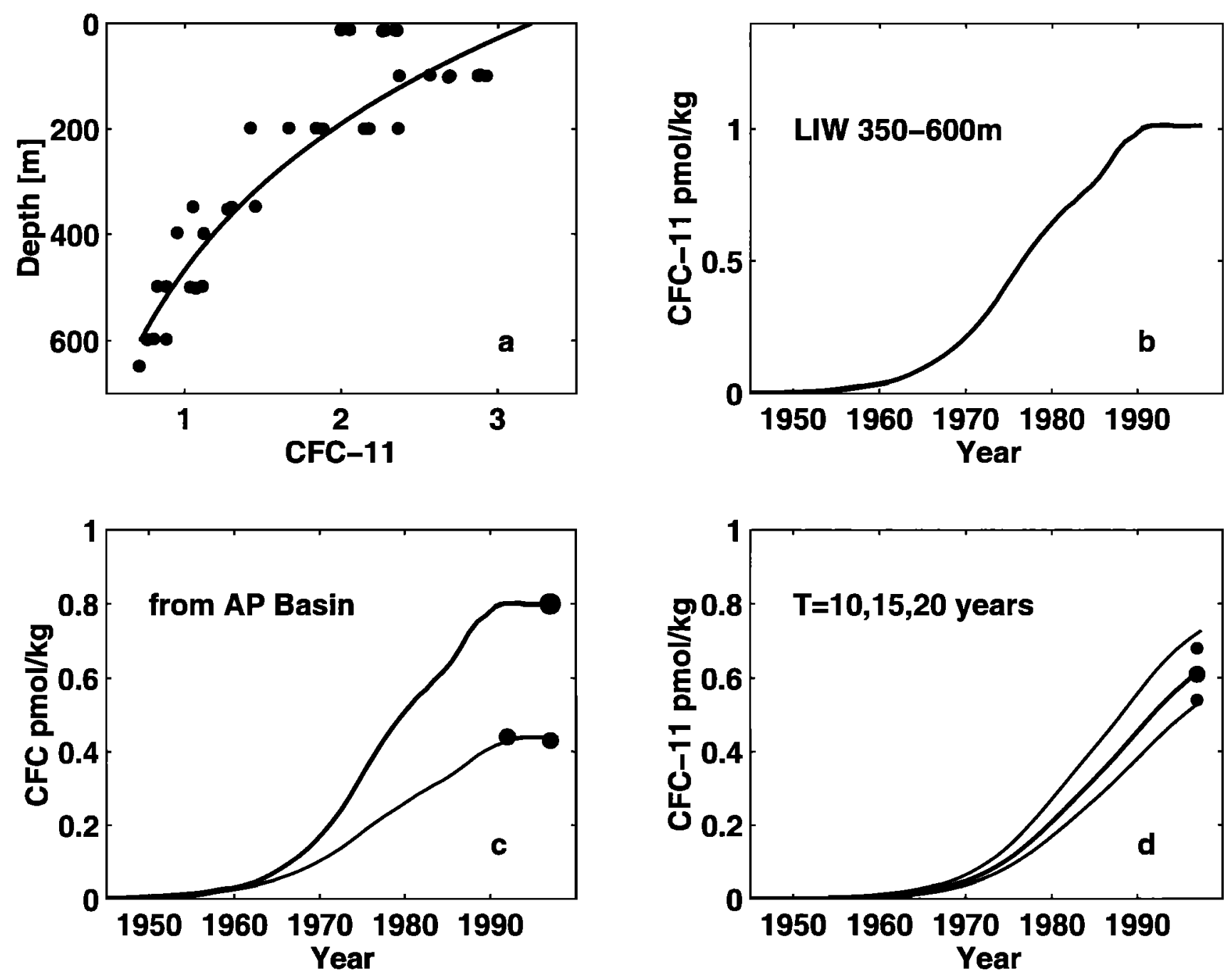

Figure 10. (a) Calculated CFC-11 profile for 1997, using the exponential fit from Rhein [1995]. The fit is compared to the observations in the Tyrrhenian Sea (dots). (b) Assumed temporal CFC evolution in the LIW averaged between 350 and $600 \mathrm{~m}$ depth. (c) Assumed temporal CFC-11 (top curve) and CFC-12 (bottom curve) evolution in the inflowing water from the Algero-Provençal Basin, including the observations from 1991 and 1997 (dots). (d) Modeled temporal evolution of the CFC signal in the deep Tyrrhenian Sea. The curves are calculated with ventilation rates of 10 (top curve), 15 (thick curve) and 20 (bottom curve) years, assuming a 2:1 mixture between water from the Algero-Provençal Basin and the LIW. The observed mean CFC concentration and standard deviations are also included as dots.

Basin and to demonstrate the presence and huge extent (600 to $1600-1900 \mathrm{~m}$ depth) of this water mass throughout the western Mediterranean. On the basis of tracer balances, the TDW outflow was estimated to be $0.4 \mathrm{~Sv}$. This transport is comparable to the deep water formation rate in the Gulf of Lions. Thus the deep water in the Algero-Provençal Basin consists of two components, which for "historical reasons" we refer to as TDW (the outflow from the Tyrrhenian Sea) and WMDW (formed by deep convection in the Gulf of Lions). Once leaving the Sardinian Channel, the TDW outflow participates in the weak cyclonic boundary current in the Algero-Provençal Basin and mixes with the interior of the basin. The distinct characteristic of the TDW out- flow, the CFC minimum, increases off the Sardinian and Corsican coast but is still present in the entire AlgeroProvençal Basin. The CFC source causing this increase is the deep wintertime convection in the Gulf of Lions, which fills the CFC minimum in the convection region owing to intense vertical mixing. Horizontal advection and mixing reestablish the CFC minimum in the Gulf of Lions, although with higher CFC values, and spread the product in the Algero-Provençal Basin. Part of this water leaves the Mediterranean through the Strait of Gibraltar, while part of it recirculates together with WMDW into the Tyrrhenian Sea. The Tyrrhenian Sea effectively removes WMDW from the Algero-Provençal Basin and, by mixing with LIW, generates the warmer, 
saline and CFC poorer TDW, which then is reinjected into the Algero-Provençal Basin at a depth level between the WMDW and the LIW.

Acknowledgments. We thank the captain and the crew of R/V Poseidon for assistance and technical support. Thanks to J. Fischer for his help in analyzing the LADCP data. M. Elbrächter, K. Bahrenfuss, O. Plähn, K. Lohmann, and D. Wilhelm performed the CFC analysis. M. Reich, A. Eisele, T. Kanzow, U. Krebs, T. Neumann, and C. Dorow ran the CTD, W. Plepp collected the helium samples and helped with the CTD. M. Reich also processed the deep float data. The work was supported by the European Community as part of the MAST III - MATER program.

\section{References}

Astraldi, M., and G. P. Gasparini, The seasonal circulation in the North Mediterranean Basin and their relationship with the atmospheric climatic conditions, J. Geophys. Res., 97, 9531-9540, 1992.

Astraldi, M., and G. P. Gasparini, The seasonal characteristics of the circulation in the Tyrrhenian Sea, in Seasonal and Interannual Variability of the Western Mediterranean Sea, Coastal Estuarine Stud., vol. 46, edited by P.E. LaViolette, pp 115-134, AGU, Washington, D.C., 1994.

Astraldi, M., G. P. Gasparini, S. Sparnocchia, M. Moretti, and $E$. Sansone, The characteristics of the water masses and the water transport in the Sicily Strait at long time scales, Bull. Inst. Oceanogr. Monaco, 17, 95-115, 1996.

Bethoux, J. P., Mean water fluxes across sections in the Mediterranean Sea, evaluated on the basis of water and salt budgets and of observed salinities, Oceanol. Acta, 3 , 79-88, 1980.

Brasseur, P., J. M. Beckers, J. M., Brankart, and R. Shoenauen, Seasonal temperature and salinity fields in the Mediterranean Sea: Climatological analyses of a historical data set, Deep Sea Res. Part I, 43, 159-192, 1996.

Bullister, J. L., and R. F. Weiss, Determination of $\mathrm{CCl}_{3} \mathrm{~F}$ and $\mathrm{CCl}_{2} \mathrm{~F}_{2}$ in seawater and air, Deep Sea Res. Part $A$, $35,839-853,1988$.

Craig, H., and R. F. Weiss, Dissolved gas saturation anomalies and excess helium in the oceans, Earth Planet. Sci. Lett., 10, 289-296, 1971.

Da Silva, A. M., C. C. Young, and S. Levitus, Atlas of Surface Marine Data, U.S. Dep. Commerce., Washington, D.C., 1994.

Davis, R. E., D. C. Webb, L. A. Regier, and J. Dufour, The autonomous Lagrangian Circulation Explorer (ALACE), J. Atmos. Oceanic Technol., 9, 264-285, 1992.

Fischer, J., and M. Visbeck, Deep velocity profiling with self-contained ADCPs, J. Atmos. Oceanic. Technol., 10, 764-773, 1993.

Fleury, M., and R. G. Lueck, Fluxes across a thermohaline interface, Deep Sea Res, Part A, 38, 745-769, 1991.

Hopkins, T. S., Recent observations in the intermediate and deep water circulation in the Southern Tyrrhenian Sea, Oceanol. Acta, 9, 41-50, 1988.

Hutchison, I., R. P. Von Herzen, K. E. Louden, J. G. Sclater, and J. Jemsek, Heat flow in the Balearic and Tyrrhenian Basins, western Mediterranean, J. Geophys. Res., 90, 685-701, 1985.
Jenkins, W. J., ${ }^{3} \mathrm{H}$ and ${ }^{3} \mathrm{He}$ in the beta triangle: Oberservations of gyre ventilation and oxygen utilization rates, $J$. Phys. Oceanogr., 17, 763-783, 1987.

Johanneesen, O. M., and O. S. Lee, Thermohaline staircase structure in the Tyrrhenian Sea, Deep Sea Res., 21, 629639, 1974.

Krahmann, G., Saisonale und zwischenjährliche Variabilität im westlichen Mittelmeer - Analyse historischer Daten, Ph.D. thesis, 168 pp., Christian Albrechts Univ. Kiel, Germany, 1997.

Lupton, J. E., and H. Craig, A major ${ }^{3} \mathrm{He}$ source at $15 \mathrm{~S}$ on the East Pacific Rise, Science, 214, 13-18, 1981.

Millot, C., Circulation in the Western Mediterranean Sea, Oceanol. Acta, 10, 143-149, 1987a.

Millot, C., The circulation of the Levantine Intermediate Water in the Algerian Basin, J. Geophys. Res., 92, 8265$8276,1987 \mathrm{~b}$.

Molcard R., and R. I. Tait, The steady state of the step structure in the Tyrrhenian. in $A$ Voyage of Discovery: George Deacon Seventicth Anniversary Volume, edited by M. Angel, pp. 221-233, Pergamon Tarrytown, N.Y., 1977.

Rhein, M., Deep water formation in the Western Mediterranean, J. Geophys. Res.. 100, 6943-6959, 1995.

Roether, W., and R. Schlitzer, Eastern Mediterranean deep water renewal on the basis of CFM and tritium data, Dyn. Atmos. Oceans, 15, 333-354, 1990.

Roether, W., V. M. Roussenov, and R. Well, A tracer study of the thermocline circulation of the eastern Mediterranean, in Ocean Processes in Climate Dynamics: Global and Mediterranean Examples, edited by P. MalanotteRizzoli and A.R. Robinson, 371-394, Kluwer Acad., Norwell, Mass., 1994.

Roether, W., R. Well, A. Putzka and C. Rüth, Component separation of oceanic helium, J. Geophys. Res., 103, 27.931-27.946, 1998.

Send, U., and J. Marshal, Integral effects of deep convection, J. Phys. Oceanogr. 25, 855-872, 1995.

Send, U., F. Schott, F. Gaillard, and Y. Desaubiers, Observation of a deep convection regime with acoustic tomography, J. Geophys. Res. 100, 6927-6941, 1995.

Well, R., Analyse der Messgüte eines massenspektrometrischen Messsystems zur Heliumisotopen-und Neon-Bestimmung an Meerwasserproben; Darstellung und Interpretation von Messergebnissen, Ph.D. thesis, pp. 167, Univ. Bremen, Bremen, Germany, 1995.

Zodiatis, G., and G. P. Gasparini, Thermohaline staircase formation in the Tyrrhenian Sea, Deep Sea Res. Part I, $43,655-678,1996$.

B. Klein, Institut für Umweltphysik, Universität Bremen, Postfach 330440, 28334 Bremen, Germany (bklein@theo.physik.uni-bremen.de)

G. Krahmann, Lamont-Doherty Earth Observatory, Columbia University, Palisades, NY 10964-8000 (krahmann@ldeo.columbia.edu)

M. Rhein, Baltic Sea Research Institute, Seestrasse 15, 18119 Rostock, Germany (email: monika.rhein@iowarnemuende.de)

U. Send, Institut für Meereskunde, Düsternbrooker Weg 20, 24105 Kiel, Germany (usend@ifm.uni-kiel.de)

(Received July 15, 1998; revised February 26, 1999; accepted March 24, 1999.) 